\title{
Pengembangan Model Pembelajaran SVRK (Self-Video Recording and Kinesthetic) Pada Mata Kuliah Bahasa Inggris Berbasis Potensi Pertanian Lokal
}

\author{
Oleh: \\ Imam Suhaimi ${ }^{1}$, Indana Mardatilla ${ }^{2}$ \\ 1,2 Dosen Fakultas Pertanian, Universitas Kahuripan Kediri \\ suhaimi_yes@kahuripan.ac.id
}

\begin{abstract}
Abstrak. Model pembelajaran SVRK (Self-Video Recording and Kinesthetic) adalah model pembelajaran bahasa yang dikembangkan oleh peneliti untuk meningkatkan kemampuan bahasa Inggris mahasiswa pertanian. Tujuan penelitian ini adalah (1) menghasilkan dan mendeskripsikan, (2) mendeskripsikan kelayakan, dan (3) mendeskripsikan model penggunaan produk dalam mata kuliah bahasa Inggris mahasiswa non jurusan Bahasa Ingris. Penelitian merupakan penelitian pengembangan yang mengacu pada model pengembangan Research and Development (R\&D) Borg and Gall. Langkah-langkah penelitin melitputi: (1) analisis potensi dan masalah, (2) mendesain produk, (3) mengumpulkan materi, (4) membuat produk awal, (5) melakukan uji ahli, (6) merevisi produk, dan (7) melakukan uji lapangan. Subjek penelitian ini adalah mahasiswa fakultas pertanian universitas se-Kota dan Kabupaten Kediri. Hasil penelitin ini menunjukkan bahwa mahasiswa mampu meningkatkan kemampuan berbahasa Inggris dengan menggunakan potensi pertanian lokal, dan melakukan evaluasi diri dengan baik.
\end{abstract}

Kata kunci: Model Pembelajaran SVRK, Potensi Pertanian Lokal

\begin{abstract}
The SVRK (Self-Video Recording and Kinetic) learning model is a language learning model developed to achieve Self Regulated Learning of agricultural students in English based on local agricultural potential. The purpose of this study is (1) to produce and describe, (2) to describe feasibility, and (3) to describe the model of product use in learning English. This research is a development research that refers to the Research and Development ( $R$ \& $D$ ) development model of Borg and Gall. The steps of research include: (1) analyzing potential and problems, (2) designing products, (3) collecting material, (4) making initial products, (5) conducting expert tests, (6) revising products, and (7) conduct field tests. The results of this research indicate that students are able to improve their English language skills by using local agricultural potential, and conduct self-evaluation well.
\end{abstract}

Keywords: SVRK Learning Model, Self-Regulated Learning, local agricultural potential 


\section{PENDAHULUAN}

Adanya inovasi teknologi informasi dan komunikasi telah mengantarkan masyarakat pada arus informasi global yang instan, adanya perkembangan zaman dapat mempengaruhi perubahan cara berfikir dan tindakan masyarakat. Perubahan-perubahan itu dapat berorientasi pertukaran cara pandang melalui budaya dan potensi antar wilayah. Kehidupan era globalisasi menuntut seseorang selalu bertindak dan berfikir dalam lingkup tradisi serta budayanya masingmasing (Baedowi, 2012: 69)

Salah satunya adalah konsep pendidikan antara potensi lokal dan global yang dapat dikombinasikan, setiap kegiatan yang dirancang dalam pembelajaran untuk membantu peserta didik mempelajari suatu kemampuan atau nilai yang baru di era globalisasi. Hilangnya batasan antara ruang dan waktu dalam berinteraksi antar individu menuntut kemampuan berkomunikasi yang efektif dan efisien. Fokus perhatian mengenai fenomena ini, telah cukup menjadi telaah penting dikalangan akademisi.

Penggunaan bahasa internasional bisa dimulai dari kalangan pegiat pertanian terpelajar, salah satunya mahasiswa pertanian. Mata kuliah bahasa Inggris bagi mahasiswa non jurusan bahasa Inggris jangan sampai hanya menjadi mata kuliah dasar tambahan yang kurang berarti, hendaknya mata kuliah bahasa Inggris sebagai English for Specific Purpose (ESP) ini menjadi titik awal pengembangan ilmu pengetahuan dan publikasi potensi lokal go international.

Model pembelajaran SVRK (Self-Video Recording and Kinesthetic) adalah sebuah model pembelajaran bahasa yang dikembangkan oleh peneliti sebagai pengembangan dari metode VAK (Visual, Auditori, dan Kinestetik) untuk mencapai Self Regulated Learning mahasiswa pertanian dalam mata kuliah bahasa Inggris (English for Specific Purpose/ESP) berbasis potensi pertanian lokal. Mahasiswa akan diajak untuk mengangkat potensi pertanian lokal yang kemudian mereka mendemonstrasikan cara pengolahan dan budidaya pertanian, jenis-jenis pertanian, hasil pertanian, pengelolaan hasil pertanian, pemanfaatan hasil pertanian, hingga pemasaran hasil dan produk pertanian yang harus mereka rekam dalam sebuah video.

Dalam pembuatan isi video tersebut, mahasiswa memperagakan kegiatan pertanian yang berbasis potensi lokal dengan tema-tema tertentu di setiap sesi, setiap tatap muka hanya akan membahas isi video yang sudah mereka rekam dan 
mendiskusikan tema yang akan dipakai pada rekaman video demonstrasi berikutnya.

Setelah itu mahasiswa diminta untuk merencanakan, menyusun, melaksanakan, dan mengevaluasi hasil video yang telah mereka buat. Hal ini bertujuan untuk kemandirian belajar mahasiswa, kemandirian mahasiswa dibutuhkan untuk mendorong mereka agar tidak selalu tergantung kepada dosen saat belajar, kebutuhan untuk mandiri saat belajar dipercaya sebagai hal yang memperkuat mahasiswa dan dapat mengetahui bahwa mahasiswa yang mandiri mampu memotivasi diri dan bertahan dalam kesulitan dan menerima kegagalan dengan sifat yang rasional (Adawiyah, 2013). Pada pengembangan model SVRK (SelfVideo Recording and Kinesthetic) yang dikembangkan oleh peneliti tidak sekedar pembuatan video, akan tetapi mahasiswa mampu melakukan Self-regulated learning.

\section{Menurut American Psychological Association Dictionary of Psychology} (VandenBos, 2007), bahwa perolehan prestasi belajar individu dalam pendidikan dapat terlihat dalam bentuk kemampuan mengerjakan tugas-tugas akademik secara umum, atau secara khusus dalam hal keterampilan-keterampilan aritmatika atau membaca. Lingkungan sosial dan target pencapaian juga memiliki peran yang penting dalam perolehan prestasi belajar individu.

Pada saat bersamaan perolehan prestasi yang rendah dapat mempengaruhi psikologis individu, belajar berdasar regulasi diri merupakan sebuah upaya individu untuk mengatur diri dalam belajar dengan mengikutsertakan kemampuan metakognisi, motivasi dan perilaku (Zimmerman \& Schunk, 2004). Adanya upaya yang dilakukan tersebut menandakan bawa adanya dorongan (drive) yang kuat dalam diri siswa dalam pencapaian prestasi belajarnya (Schunk, 2012). Selain itu tersedianya lingkungan yang mendukung dan tepatnya tindakan yang dilakukan akan mendatangkan dorongan.

Metode VAK (Visual, Auditori, dan Kinestetik) yang sudah banyak diterapkan oleh pendidik utamanya sekolah dasar dan menengah, yang menitik beratkan peserta didik untuk belajar sesuai dengan minat dan bakatnya. Sebuah penelitian ekstensi, khususnya di Amerika Serikat, yang dilakukan oleh Profesor Ken dan Rita Dunn dari Universitas St. John, di Jamaica, New York, dan para pakar pemrograman Neuro-Linguistik seperti, Richard Bandler, John Grinder, dan Michael Grinder, telah mengidentifikasi tiga gaya belajar dan komunikasi yaitu 
Gaya Visual, Gaya Auditori, dan gaya Kinesthetik (Rose, Colin dan Nicholl,2002, p. 130).

Sedangkan Model SVRK sebagai pengembangan dari VAK, peneliti ingin menerapkan model pembelajaran dari sudut pandang yang lain yaitu peserta didik (dalam hal ini mahasiswa) melakukan gerakan-gerakan dan improvisasi yang direkam secara mandiri dan dievaluasi sendiri dengan tanpa memandang minat dan bakat akan tetapi mengekplorasi potensi latar belakang keilmuan mereka untuk di ekspos secara global.

Penelitian ini berupaya memberikan model pembelajaran bahasa Inggris untuk mengangkat potensi pertanian lokal agar mampu diterima oleh mahasiswa dalam mengkomunikasikan potensi pertanian lokal kabupaten dan kota Kediri dalam kajian ilmu pengetahuan sosial, bahasa dan seni.

Penelitian ini mengangkat potensi pertanian lokal Kediri, dimana Kediri merupakan salah satu lumbung padi di Jawa Timur. Tak hanya padi, Kediri juga banyak menghasilkan jagung, ubi kayu, ubi jalar, kacang tanah dan lainnya. Penghasil kacang tanah terbesar di Kediri berada di kecamatan Kras, disusul dengan Banyakan.

Dalam analisis yang dilakukan oleh Rasyid (2016) terhadap sektor ekonomi yang menjadi unggulan kompetitif dan dan spesialisasi kabupaten Kediri yaitu sektor pertanian menjadi rata-rata kontribusi sektoral tertinggi.

Luas Kediri hanya 5\% dari Jawa Timur, namun rupanya potensi bisnis di wilayah Kediri cukup menjanjikan. Wilayah yang berbatasan langsung dengan gunung Kelud ini termasuk kabupaten yang aktif pada roda perekonomian. Kediri memiliki sektor yang beragam, salah satunya perkebunan. Meski Kediri termasuk lokasi yang terik, namun tanah di kabupaten dan kota Kediri begitu subur, cocok untuk usaha perkebunan, seperti perkebunan coklat.

Potensi semacam ini yang perlu diekspos secara luas, salah satunya dengan melakukan penelitian dan kemudian mempublikasikan secara luas hingga ke manca negara. Tugas seperti ini tidak mungkin dilakukan oleh petani tradisional, mahasiswa pertanian sebagai kalangan calon petani "terdidik" haruslah menguasai bahasa internasional jika ingin mempublikasikan potensi pertanian lokal. 
Juga sebaliknya, publikasi internasional yang memuat ilmu dan pengetahuan tentang pertanian perlu diketahui oleh pelaku pertanian termasuk mahasiswa. Ketika mahasiswa mampu menguasai bahasa Inggris sebagai bahasa internasional maka tujuan tersebut akan lebih mudah tercapai.

Jenis metode penelitian yang digunakan pada penelitian ini adalah metode penelitian dan pengembangan (Research and Development atau $R \& D$ ). Samsudi (2006) menjelaskan penelitian dan pengembangan berupaya menghasilkan suatu komponen dalam sistem pendidikan, melalui langkah-langkah pengembangan dan validasi.

Dari uraian dan identifikasi di atas, rumusan penelitian ini untuk mengetahui "Bagaimana karakteristik pengembangan model pembelajaran SVRK (Self-Video Recording and Kinesthetic) dalam mata kuliah bahasa Inggris berbasis potensi pertanian lokal?

\section{HASIL DAN PEMBAHASAN}

\section{Hasil}

Penelitian Pengembangan (Research and Development atau $R \& D$ ) digunakan apabila peneliti bermaksud menghasilkan produk tertentu, sekaligus menguji kelayakan produk tersebut. Dalam penelitian pengembangan ini menggunakan model prosedural yang mendeskripsikan tahapan yang harus diikuti untuk menghasilkan produk model pembelajaran. Untuk tahap awal penelitian, peneliti menggunakan pendekatan kualitatif dengan tujuan memperoleh data faktual di lapangan.

Secara garis besar, keseluruhan bagan alur tahapan rancangan penelitian dan pengembangan dapat dilihat pada gambar bagan berikut ini.

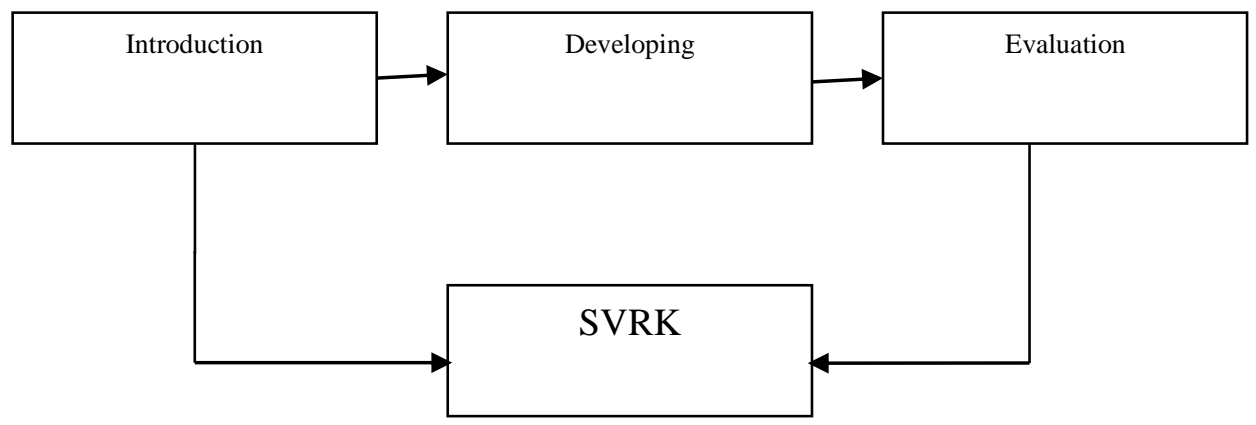


AKSARA Jurnal Bahasa dan Sastra

Vol. 19, No. 2, Hal. 68 - 88, Oktober 2018

http://jurnal.fkip.unila.ac.id/index.php/aksara

Bagan 1. Model Pembelajaran S-V-R-K (Self-Video Recording and Kinesthetic) Untuk Meningkatkan Self-Regulated Learning Mahasiswa Pertanian Dalam Mata Kuliah Bahasa Inggris Berbasis Potensi Pertanian Lokal

\section{Pengumpulan Data Informasi Berdasarkan Lapangan}

Kegiatan pengumpulan data informasi dalam penelitian pengembangan model pembelajaran SVRK (Self-Video Recording and Kinesthetic) untuk meningkatkan self-regulated learning mahasiswa pertanian dalam mata kuliah bahasa Inggris berbasis potensi pertanian lokal dilakukan melalui observasi kegiatan dan hasil pertanian lokal dari berbagai sumber di Kediri. Adapun potensi pertanian lokal yang dikumpulkan dari 4 unsur dari lokasi yang terdapat di Kediri yang dilakukan secara bertahap dan berkesinambungan dalam waktu dan tempat yang berbeda. Hasil dari tahap ini adalah melihat langsung budidaya dan hasil pertanian lokal Kediri meliputi tanaman sayuran, tanaman buah, tanaman hias, dan tanaman obat dilakukan oleh masyarakat Kediri.

\section{Pengumpulan Informasi Potensi Pertanian Lokal Kediri}

Setelah tahap pengumpulan informasi berdasarkan lokasi di lapangan dan jenis pertanian maka peneliti melakukan pengumpulan informasi berdasarkan wawancara beberapa tokoh masyarakat di Kediri. Kegiatan ini bertujuan untuk menghubungkan data dilapangan tentang pengembangan model pembelajaran SVRK (Self-Video Recording and Kinesthetic) untuk meningkatkan selfregulated learning mahasiswa pertanian dalam mata kuliah bahasa Inggris berbasis potensi pertanian lokal, dengan informasi yang terpercaya di daerahdaerah yang telah ditentukan sebelumnya. Hasil dari tahap ini adalah wawancara dengan ahli bidang pertanian dan tokoh msyarakat pelaku pertanian.

Pengumpulan data ini diperlukan untuk menentukan tema uji coba pembuatan video yang dilakukan oleh peneliti, dengan tema yang tepat dan sesuai dengan potensi pertanian lokal, mahasiswa lebih termotivasi untuk melakukan pembuatan video dan melaksanakan self-regulated learning

\section{Studi Literatur Potensi Pertanian Lokal}

Pada tahap ini juga perlu pengembangan dan pengkajian ulang bahan untuk penelitian dengan rujukan literatur dan berkonsultasi dengan para ahli yang bersangkutan. Adapun pelaksanaan dengan mengumpulkan sumber rujukan metode pembelajaran yang meliputi pencarian, penyeleksian, dan menyusun draft sumber rujukan. Sumber rujukan bahan literatur dapat memperkuat bahan penelitian dalam mendalami pengenalan potensi pertanian lokal Kediri. 


\section{Studi Literatur Mengenai Metode Pembelajaran Bahasa Inggris Mahasiswa Pertanian}

Mata kuliah bahasa Inggris pada mahasiswa pertanian adalah mata kuliah umum wajib di beberapa perguruan tinggi, untuk itu perlu perhatian pada mata kuliah ini agar tidak sekedar menjadi mata kuliah pelengkap. Pemanfaatan dan penggunaan metode pembelajaran yang relevan dalam kelas dapat mengoptimalkan proses pembelajaran. Model pembelajaran SVRK (Self-Video Recording and Kinesthetic) untuk meningkatkan self-regulated learning mahasiswa pertanian dalam mata kuliah bahasa Inggris berbasis potensi pertanian lokal sebagai berikut:

a) Buku model pembelajaran bahasa inggris untuk mahasiswa pertanian

b) Rujukan ini mempermudah dalam mengidentifikasi pembelajaran bahasa inggris yang mengutamakan kemampuan vocabulary dan pronounciation dalam mengidentifikasi pertanian lokal Kediri

c) Buku referensi pembelajaran bahasa Inggris dalam tingkat perguruan tinggi non jurusan Bahasa Inggris

d) Rujukan tersebut bertujuan untuk menyesuaikan kemampuan mahasiswa dalam aspek psikologi dan karakteristiknya.

e) Kurikulum perguruan tinggi

f) Untuk menyesuaikan program pembelajaran bahasa inggris di tingkat program perguruan tinggi berdasarkan rencana pembelajaran

\section{Aktifitas dan istilah-istilah pertanian Pertanian Lokal Sebagai Tema Pembelajaran Bahasa Inggris}

Pada tahap ini peneliti melakukan pemunculan aktifitas dan istilah-istilah pertanian lokal Kediri berdasarkan unsur kuantitas penggunaannya . Adapun jenis-jenis aktifitas dan istilah-istilah pertanian lokal Kediri berdasarkan unsur kuantitas penggunaannya sebagai berikut:

Tabel 1: Aktifitas dan Istilah-Istilah Pertanian Lokal Kediri Berdasarkan Unsur Kuantitas Penggunaannya

\begin{tabular}{l|l|l}
\hline No. & \multicolumn{1}{|c|}{ Klasifikasi } & \multicolumn{1}{c}{ Kosa kata } \\
\hline 1. & \multirow{2}{*}{ Aktifitas Pertanian } & Crop \\
\cline { 3 - 3 } & & Crop spraying \\
\cline { 3 - 3 } & & Improvement in agriculture \\
\cline { 3 - 3 } & & Irrigation \\
\cline { 3 - 3 } & Istilah-istilah pertanian & Plow \\
\cline { 3 - 3 } & & Agricultural land \\
\cline { 3 - 3 } & & Agriculturist \\
\hline
\end{tabular}




\begin{tabular}{l|l}
\hline \multirow{n}{*}{} & Farmer \\
& Fertilizer \\
& Harvest \\
& Hoe \\
\hline & Orchard \\
& Rice \\
& Rice mill \\
& Straw \\
\cline { 2 - 2 } & Vegetable garden \\
\hline
\end{tabular}

Klasifikasi Potensi Pertanian Lokal Sebagai Tema Pembelajaran Bahasa Inggris

Pada tahap ini peneliti melakukan klasifikasi pertanian lokal Kediri berdasarkan unsur potensi . Adapun jenis-jenis potensi pertanian lokal Kediri diklasifikasikan sebagai berikut.

Tabel 2: Klasifikasi jenis-jenis potensi pertanian lokal Kediri

\begin{tabular}{l|l|l}
\hline No & \multicolumn{1}{|c|}{ Unsur Potensi Pertanian } & \multicolumn{1}{c}{ Jenis Jenis Pertanian } \\
\hline 1 & Sayuran & b. Tomato \\
\hline & & c. Cucumber \\
\hline & & d. mustard \\
\hline & & e. Carrot \\
\hline & & f. Kobis \\
\hline & & g. Celery \\
\hline & Tanaman Hias & h. Broccoli \\
\hline & & i. Bean \\
\hline & & a. Orchid \\
\hline & & b. Rose \\
\hline & & c. Jasmine \\
\hline & & d. Kmboja \\
\hline & & e. Dahlia \\
\hline 4 & Buah-buahan & a. Banana \\
\hline
\end{tabular}




\begin{tabular}{l|l|l}
\hline & & f. Orange \\
\hline & & g. Wine \\
\hline & & d. Durian \\
\hline & & e. Manggo \\
\hline & & f. Rambutan \\
\hline 5. & Tanaman obat & a. Ginger \\
\hline & & b. Temu Lawak \\
\hline & & c. Betel \\
\hline & & d. Turmeric \\
\hline & & e. Aloe vera \\
\hline & & f. Spinach thorn \\
\hline & & g. Beluntas \\
\hline
\end{tabular}

Merumuskan Materi Model Pembelajaran SVRK (Self-Video Recording and Kinesthetic) Untuk Meningkatkan Self-Regulated Learning Mahasiswa Pertanian Dalam Mata Kuliah Bahasa Inggris Berbasis Potensi Pertanian

\section{Lokal}

Adapun langkah dalam merumuskan model pembelajaran yang memiliki hasil sebagai berikut :

a. Menelaah silabus pembelajaran bahasa inggris di tingkat pergurun tinggi non jurusan bahasa Inggris

b. Mengidentifikasi Standar Kompetensi dan Kompetensi Dasar

c. Mencari rujukan keilmuan yang terkait

d. Mendiskusikan rencana pembelajaran

e. Mengembangkan model pembelajaran

f. Menentukan metode dan simulasi

g. Menentukan penilaian hasil belajar

\section{Merancang Produk Model Pembelajaran Berupa Karangan (monolog)}

Tahap ini diawali dengan penelaah konsep model cerita kegiatan dan potensi pertanian lokal dalam bahasa Indonesia ke dalam konsep berbahasa inggris. Langkah awal menentukan ide sentral dalam cerita pertanian lokal Kediri, kemudian merancang sinopsis yang terdiri dari :

a. Pokok pikiran, kalimat pokok atau kalimat inti. 
b. Mengembangkan catatan dalam konsep bahasa Indonesia kedalam bahasa Inggris dengan memfokuskan kemampuan vocabulary dan pronounciation cerita pertanian lokal Kediri.

c. Memilih kalimat tunggal, meringkas kalimat menjadi frase, frase menjadi kata, mempertahankan ide dengan menyusun naskah monolog

d. Merancang produk model pembelajaran SVRK berupa gambar ilustrasi dan buku rujukan.

Penelitian pengembangan model pembelajaran SVRK (Self-Video Recording and Kinesthetic) untuk meningkatkan self-regulated learning mahasiswa pertanian dalam mata kuliah bahasa Inggris berbasis potensi pertanian lokal memiliki jenis dan karakteristik yaitu alur model pembelajaran. Model pembelajaran SVRK terdiri dari penyajian visual dan uraian dengan maksud menggambarkan suatu ide dan data kejadian tentang pertnian lokal melalui pembelajaran bahasa Inggris

Adapun pengembangan Model pembelajaran SVRK dalam pembelajaran bahasa inggris untuk meningkatkan self-regulated learning mahasiswa pertanian dalam mata kuliah bahasa Inggris berbasis potensi pertanian lokal sebagai berikut:

a. Model Pembelajaran yang mengajak mahasiswa untuk membuat materi atau tema pertanian kemudian direkam dalam sebuah video dengan polah gerak layaknya melakukan aktifitas seperti yang diperbincangkan

b. Mahasiswa memberikan penilaian terhadap hasil video yang telah mereka buat, mahasiswa menilai dari vocabulary, structure, pronunciation, serta kinesthetik yang diperagakan lalu memberikan skor penilaian.

c. Pembuatan video dan model pembelajaran berbasis potensi pertanian lokal mengilustrasikan sebagai motivasi agar mahasiswa mampu meningkatkan hasil potensi pertanian lokal.

d. Model SVRK untuk meningkatkan self-regulated learning mahasiswa pertanian dalam mata kuliah bahasa Inggris berbasis potensi pertanian juga diuraikan dalam sebuah buku panduan penggunaan model ini, dengan adanya uraian dan contoh video dari mahasiswa sebagai model untuk pelengkap buku diharapkan menjadi motivasi bagi peneliti dan juga pengajar bahasa Inggris untuk menggunakan dan menerapkan kepada mahasiswa.

Adapun hasil ujicoba model pembelajaran SVRK (Self-Video Recording and Kinesthetic) untuk meningkatkan self-regulated learning mahasiswa pertanian dalam mata kuliah bahasa Inggris berbasis potensi pertanian lokal dalam penelitian ini sebagai berikut: 
a. Perlu apersepsi atau introduction tentang materi yang akan disampaikan dalam bahasa Indonesia setelah itu diterapkan pembelajaran bahasa inggris yang dimulai dengan langkah pembelajaran seperti penguatan belajar

b. Pengenalan objek dalam melakukan percakapan tentang potensi pertanian melalui pengenalan kosa kata seputar pertanian lokal

c. Perlu penyisipan materi dalam berkomunikasi dengan berbahasa Indonesia dalam menjelaskan kata maupun kosakata berbahasa inggris

d. Penyampaian materi seharusnya ditekankan pada kosakata dan pelafalan bahasa inggris secara jelas

e. Tahap konfirmasi dalam materi pembuatan video harus disampaikan potensipotensi pertanian lokal menggunakan analogi cerita potensi pertanian dengan kehidupan masa kini melalui bahasa inggris dan bahasa indonesia

f. Tahap evaluasi perlu dibantu oleh dosen untuk menceritakan kembali menggunakan bahasa Inggris

\section{Merancang Produk Model Pembelajaran SVRK Berupa Gambar Ilustrasi} Penelitian pengembangan model pembelajaran SVRK (Self-Video Recording and Kinesthetic) untuk meningkatkan self-regulated learning mahasiswa pertanian dalam mata kuliah bahasa inggris berbasis potensi pertanian lokal memiliki jenis dan karakteristik yaitu alur model pembelajaran. Model pembelajaran SVRK terdiri dari penyajian visual menggunakan titik, garis, bentuk, warna dan teksture maya dengan maksud untuk mengikhtisarkan, menggambarkan suatu ide, data atau kejadian dari aktifitas pertanian lokal kediri melalui pembelajaran berbahasa inggris. Adapun ciri-ciri dari pengembangan model pembelajaran SVRK (Selfvideo Recording and Kinesthetic) dalam pembelajaran bahasa inggris untuk meningkatkan self-regulated learning mahasiswa pertanian dalam mata kuliah bahasa Inggris berbasis potensi pertanian lokal sebagai berikut:

1. Model SVRK untuk pembelajaran bahasa inggris tentang potensi pertanian lokal Kediri melalui alur cerita dan keterangan aktifitas pertanian termasuk karya dua dimensi dengan bentuk format bahan ajar pembelajaran.

2. Dari segi visualisasi terdiri dari gambar, video, dan teks sebagai penjelasan dari gambar tersebut.

3. Objek gambar berbentuk tunggal artinya menjelaskan suatu kejadian dalam satu adegan dalam karya gambar tersebut.

4. Pembuatan video atau gambar dengan penjelasan dan teks dalam bahasa inggris tentang potensi pertanian lokal Kediri bertujuan sebagi penggerak perhatian, mengilustrasikan suatu pokok masalah sebagai alat untuk memotivasi dan keaktifan mahasiswa. 
Model SVRK dalam pembelajaran bahasa Inggris untuk meningkatkan selfregulated learning mahasiswa pertanian dalam mata kuliah bahasa Inggris berbasis potensi pertanian lokal juga termasuk suplemen. Adapun yang dimaksud suplemen adalah hasil karya yang dapat memberikan peluang kepada peserta didik untuk memenuhi minat-minat individual mereka. Melalui suplemen (model SVRK) dalam format yang lebih kecil dan menarik mahasiswa akan menambah perbendaharaan, pengetahuan, keterampilan dan sikap-sikap baru dalam mengapresiasikan serta melestarikan potensi pertanian lokal Kediri.

\section{Merancang Produk Model Pembelajaran SVRK Berupa Buku Referensi}

Penelitian pengembangan model pembelajaran SVRK (Self-Video Recording and Kinesthetic) untuk meningkatkan self-regulated learning mahasiswa pertanian dalam mata kuliah bahasa inggris berbasis potensi pertanian lokal perlu disajikan dalam bentuk buku referensi, buku refensi dibutuhkan sebagai media evaluasi dan vadidasi oleh para ahli, selain itu sebagai bukti produk untuk dapat disebarluaskan sebagaimana dapat bermanfaat untuk diterapkan oleh khalayak luas. Buku referensi model pembelajaran SVRK (Self-video Recording and Kinesthetic) dalam pembelajaran bahasa inggris untuk meningkatkan self-regulated learning mahasiswa pertanian dalam mata kuliah bahasa Inggris berbasis potensi pertanian lokal memiliki bagian-bagian sebagai berikut:

1. Penjelasan tentang kegunaan dan fungsi model pembelajaran SVRK dalam mata kuliah bahasa Inggris untuk mahasiswa non jurusan bahasa Inggris dan juga sebagai referensi mahasiswa dan dosen jurusan bahasa Inggris untuk mata kuliah ESP (English for Specific Purpose)

2. Buku referensi ini menyajikan beberapa bab untuk memudahkan pembaca dalam memahami model pembelajaran SVRK.

3. Penyajian contoh-contoh topik selain pertanian untuk memudahkan pembaca dalam berimprovisasi dalam pembelajaran English for Spesific Purpose.

\section{Validasi para ahli dalam Hasil Produk}

Tahap validasi dilakukan para ahli yaitu ahli pembelajaran bahasa Inggris, ahli model pembelajaran dan ahli pertanian lokal Kediri untuk diminta memberikan penilaian dan saran terhadap produk bahan ajar berupa model pembelajaran dalam bahasa inggris. Instrumen validator para ahli untuk produk model pembelajaran dan potensi pertanian lokal Kediri dalam bahasa inggris harapannya disusun menjadi buku pegangan dosen. Adapun rangkuman hasil validator para ahli disajikan dalam tabel berikut ini. 
AKSARA Jurnal Bahasa dan Sastra

Vol. 19, No. 2, Hal. 68 - 88, Oktober 2018

http://jurnal.fkip.unila.ac.id/index.php/aksara

Table 3: Data Hasil Validator Para Ahli Terhadap Produk bahan ajar model Pembelajaran SVRK dalam Bahasa Inggris

\begin{tabular}{|c|c|c|c|}
\hline \multirow[b]{2}{*}{ No } & \multirow[b]{2}{*}{ Bagian/Komponen/Sub komponen } & \multicolumn{2}{|l|}{ Hasil Penilaian } \\
\hline & & Rata-Rata Skor & Keterangan \\
\hline $\mathrm{I}$ & II & III & IV \\
\hline \multirow[t]{2}{*}{$\underline{\mathrm{A}}$} & Kelengkapan Penvajian & & \\
\hline & Penampilan : & & \\
\hline$\overline{1}$ & Pendahuluan/pembuka & 4.6 & sesuai \\
\hline 2 & Keterkaitan & 4.67 & sesuai \\
\hline 3 & Penggunaan Huruf & 5.00 & sangat sesuai \\
\hline \multicolumn{2}{|c|}{ Rata-rata skor } & 4,78 & sangat baik \\
\hline $\mathrm{B}$ & Pengorganisasian Isi & & \\
\hline 1 & Pengelompokan isi materi & 5,00 & sangat jelas \\
\hline 2 & Pengantar tulisan & 5.00 & sangat jelas \\
\hline 3 & Pencatuman literatur & 3.67 & cukup jelas \\
\hline 4 & Sistematika penulisan & 5,00 & sangat jelas \\
\hline 5 & Penyampaian bahasa & 5.00 & sangat jelas \\
\hline$\underline{6}$ & Penggunaan kalimat & 5.00 & sangat ielas \\
\hline \multicolumn{2}{|c|}{ Rata-rata skor } & 4.67 & sangat baik \\
\hline$\overline{\mathrm{C}}$ & Penvaiian Isi & & \\
\hline 1 & Penyampaian bahasa & 4.00 & jelas \\
\hline 2 & Penggunaan kalimat & 5.00 & sangat jelas \\
\hline 3 & Kelengkapan materi & 4.67 & jelas \\
\hline \multicolumn{2}{|c|}{ Rata-rata skor } & 4,56 & sangat baik \\
\hline & & \multicolumn{2}{|l|}{ HasilPenilaian } \\
\hline No & Bagian/Komponen/Sub komponen & Rata-Rata Skor & Keterangan \\
\hline I & II & III & IV \\
\hline $\mathrm{D}$ & Kelengkapan Isi & & \\
\hline 1 & Landasan Konseptual Pengembangan & 4.78 & tepat guna \\
\hline 2 & Silabus/RPS & 4.48 & tepat guna \\
\hline 3 & RPP & 4.96 & tepat guna \\
\hline 4 & Bahan ajar & 4.71 & tepat guna \\
\hline \multicolumn{2}{|c|}{ Rata-rata skor } & 4,73 & sangat baik \\
\hline \multicolumn{2}{|c|}{ Total Skor } & 4,68 & $\begin{array}{l}\text { (valid) digunakan } \\
\text { dengan revisi sedikit }\end{array}$ \\
\hline
\end{tabular}


AKSARA Jurnal Bahasa dan Sastra

Vol. 19, No. 2, Hal. 68 - 88, Oktober 2018

http://jurnal.fkip.unila.ac.id/index.php/aksara

\section{Evaluasi dari Masukan dan Saran Para Ahli}

Adapun rekomendasi dari para ahli validator yaitu dapat digunakan dengan revisi kecil. Hal ini berarti secara garis besar baik komponen kelengkapan penyajian dan kelengkapan isi yang berkaitan dengan pengembangan model pembelajaran SVRK untuk meningkatkan self-regulated learning mahasiswa pertanian dalam mata kuliah bahasa Inggris berbasis potensi pertanian lokal dapat dikategorikan sudah baik dan layak digunakan.

Para ahli validator memberi komentar bahwa produk model pembelajaran SVRK untuk meningkatkan self-regulated learning mahasiswa pertanian dalam mata kuliah bahasa Inggris berbasis potensi pertanian lokal dapat dikemas menjadi buku pegangan dosen dan mahasiswa dipandang sudah baik, yaitu: (a) telah sesuai dengan tujuan pembelajaran bahasa inggris untuk mahasiswa pertanian, (b) cukup jelas dan dapat diterapkan oleh dosen bahasa Inggris yang mengajar di fakultas pertanian, (c) dapat digunakan dosen sebagai acuan mengajar dan pengayaan materi, dan (d) dikatakan produk berbasis potensi pertanian lokal Kediri dalam pembelajaran bahasa Inggris tersebut sangat baik.

Meskipun demikian ada beberapa catatan saran perbaikan dari evaluator, yaitu: (a) bagian kelengkapan penyajian pada komponen penampilan berupa lay-out agar diatur margin dengan mempertimbangkan estetikanya, (b) pada bagian kelengkapan penyajian pada komponen pengorganisasian isi, pencantuman literatur perlu dibuat sesuai dengan aturan penulisan ilmiah, (c) perlu pembenahan teknis dan kecermatan dalam penulisan.

\section{Tahap Ujicoba Produk}

Untuk mendukung terlaksanannya hasil penelitian Pengembangan model pembelajaran SVRK untuk meningkatkan self-regulated learning mahasiswa pertanian dalam mata kuliah bahasa Inggris berbasis potensi pertanian lokal telah diaplikasi hasil berupa ujicoba dalam pembelajaran bahasa inggris di kelas yang diterapkan di fakultas pertanian Universitas Kadiri (UNIK), Universitas Islam Kadiri (UNISKA), Universitas Wahidiyah (UNIWA), dan Universias Kahuripan Kediri (UKK) dilanjutkan tahap evaluasi dilaksanakan dengan mereview proses pembelajaran potensi pertanian lokal Kediri.

Dengan tujuan mengetahui kekurangan dalam produk pengembangan model pembelajaran SVRK untuk meningkatkan self-regulated learning mahasiswa pertanian dalam mata kuliah bahasa Inggris berbasis potensi pertanian lokal. Hasil dari tahap ini adalah pengadaan produk dalam ujicoba masih mengalami 
kekurangan dalam jumlahnya sehingga dalam pelaksanaan pembelajaran belum maksimal dalam penyampaian materi.

\section{Menghasilkan Produk.}

Pengembangan model pembelajaran SVRK untuk meningkatkan self-regulated learning mahasiswa pertanian dalam mata kuliah bahasa Inggris berbasis potensi pertanian lokal memiliki komponen materi dan hasil proses selama kegiatan penelitian dengan digandakan yang diharapkan sebagai pegangan untuk para dosen pengampu mata kuliah bahasa Inggris pada jurusan atau fakultas pertanian khususnya dan jurusan non bahasa Inggris pada umumnya untuk bahan pembelajaran bahasa inggris pada masing-masing perguruan tinggi.

\section{Meningkatkan Self-Regulated Learning Mahasiswa}

Self-regulated learning adalah kegiatan dimana mahasiswa belajar secara aktif sebagai pengatur proses belajarnya sendiri, mulai dari merencanakan, memantau, mengontrol dan mengevaluasi dirinya secara sistematis untuk mencapai tujuan dalam belajar. Taraf Self-regulated learning diukur dengan skala self-regulated learning. Semakin tinggi skor yang diperoleh menunjukkan semakin tinggi kemampuan self-regulated learning siswa.

Dengan penerapan Model Pembelajaran SVRK (Self-Video Recording and Kinesthetic) pada mahasiswa pertanian di empat universitas di kota dan kabupaten Kediri, dari hasil penelitian diperoleh bahwa $100 \%$ mahasiswa yang menjadi subjek dalam penelitian ini melakukan pembuatan video dengan gerakan-gerakan dan mengevaluasi hasil video tersebut. Peneliti telah menyebar angket untuk responden agar mengisi bagian-bagian mana yang dievaluai diantara empat komponen (boleh memilih lebih dari satu) yaitu tentang (1) kesesuaian gerakan, (2) pengucapan (pronunciation), (3) tata bahasa (grammar), dan (4) kosa kata (vocabulary). Adapun hasil yang dievalui oleh mahasiswa yaitu:

a) $92 \%$ mengevaluasi gerakan yang belum sesuai dengan tema "conversation"

b) $90 \%$ mengevaluasi ketepatan pengucapan (pronunciation)

c) $80 \%$ mengevaluasi tata bahasa (grammar) yang digunakan

d) $85 \%$ mengevaluasi kosa kata (vocabulary) yang digunakan

Dari uraian tersebut di atas dapat disimpulkan bahwa mahasiswa lebih cenderung mengevaluasi gerakan-gerakan yang sesuai dengan tema percakapan yang dibuat dalam video, dengan demikian tujuan model pembelajaran SVRK (Self-Video Recording and Kinesthetic) dapat tercapai dengan skor tertinggi pada ranah kinesthetic-nya. Kemudian muncul evaluasi yang dominan kedua adalah 
pengucapan (pronunciation), mahasiswa lebih menekankan pada kedua faktor tersebut (khinestetik dan pronunciation) karena keduanya yang paling tampak saat melihat hasil rekaman video yang telah dibuat.

\section{Contoh Petunjuk Pelaksanaan Model pembelajaran SVRK (Self-Video Recording and Kinesthetic)}

Model pembelajaran SVRK (Self-Video Recording and Kinesthetic) adalah sebuah model pembelajaran bahasa yang dikembangkan oleh peneliti sebagai pengembangan dari metode VAK (Visual, Auditori, dan Kinestetik) dalam mata kuliah bahasa Inggris (English for Specific Purpose/ESP) untuk meningkatkan pemahaman mahasiswa non jurusan bahasa Inggris dalam belajar bahasa Inggris, meningkatkan kemampuan kosa kata dan pelafalan dalam bahasa Inggris. Penelitian ini dilaksanakan dengan mengambil subjek mahasiswa pertanian di kabupaten dan kota Kediri, namun metode SVRK ini dapat pula digunakan untuk mahasiswa selain pertanian dengan mengganti tema dan topik sesuai dengan kebutuhan. Maka dari itu dari hasil penelitian pengembangan ini, peneliti juga perlu menuliskan petunjuk penggunaan model pembelajaran SVRK agar tidak membatasi penggunaannya meskipun petunjuk berikut di bawah secara spesifik dibuat petunjuk untuk pembelajaran bahasa Inggris bagi mahasiswa pertanian.

Berikut petunjuk Pelaksanaan Model pembelajaran SVRK (Self-Video Recording and Kinesthetic) untuk pembelajaran bahasa Inggris mahasiswa pertanian, petunjuk ini juga mengkombinasikan self-regulated learning sesuai hasil penelitian yang telah dilakukan oleh peneliti.

Tahapan pelaksanaannya sebagai berikut:

1. Persiapkan alat perekam video yang memadai.

2. Bentuklah kelompok kecil antara 3-4 orang mahasiswa, kemudian berilah tugas masingmasing sebagai pemeran dalam video, sebagai penilai, dan sebagai perekam. Tugas tersebut dapat diroling sehingga seluruh mahasiswa mendapat giliran pada setiap peran.

3. Perisapkan materi bahasa Inggris tentang pertanian, mulai dari kosa kata hingga aktifitas pertanian, lalu dibuatlah sebuah percakapan antara 2-3 orang.

4. Buatlah kalimat percakapan beserta petunjuk gerakan yang harus dilakukan oleh mahasiswa.

5. Buatlah chek list evaluasi terhadap isi materi video (seperti pengucapan, kosa kata, gramatikal, dan ekspresi gerakan apakah sudah sesuai dengan isi percakapan atau belum). 
6. Mintalah mahasiswa untuk mempraktikkan percakapan tentang pertanian dan direkam, kemudian mahasiswa yang lain memberikan evaluasi dan penilaian terhadap isi video tersebut.

7. Dosen memberikan masukan dan perbaikan terhadap isi percakapan (seperti Pronunciation) dalam video.

8. Materi video bisa dibuat berfariasi dan berasal dari mahasiswa.

Dalam pelaksanaannya, model pembelajaran SVRK bisa menggunakan topik dan tema berfariasi. Penelitian ini menggunakan sampel mahasiswa pertanian dan pembelajaran bahasa Inggris dengan tema pertanian untuk membuat sebuah pengembangan model pembelajaran bahasa Inggris untuk mahasiswa non jurusan bahasa Inggris, penelitian ini bukan untuk membatasi ruang penggunaan model SVRK.

Selain pembelajaran bahasa Inggris, model pembelajaran SVRK sangat memungkinkan untuk pembelajaran bahasa selain bahasa Inggris, penelitian ini mengakomodir untuk model pembelajaran bahasa asing terutama bagi mahasiswa.

\section{Pembahasan}

Model pembelajaran SVRK (Self-Video Recording and Kinesthetic) adalah sebuah model pembelajaran bahasa yang dikembangkan oleh peneliti sebagai pengembangan dari metode VAK (Visual, Auditori, dan Kinestetik) untuk mencapai Self Regulated Learning mahasiswa pertanian dalam mata kuliah bahasa Inggris (English for Specific Purpose/ESP) berbasis potensi pertanian lokal Kediri. Hasil dari penelitian ini diharapkan tidak hanya sekedar dipergunakan dalam mata kuliah bahasa Inggris pada mahasiswa pertanian semata, akan tetapi bisa lebih luas diterapkan pada mahasiswa jurusan atau program studi yang lain.

Dalam pembelajaran bahasa Inggris untuk orang dewasa dalam hal ini mahasiwa, Self-regulated Learning dihadirkan sebagai partisipasi mahasiswa untuk aktif secara metakognisi, perilaku, dan motivasi belajar. Self-regulated learning mampu mengarahkan mahasiswa untuk merencanakan, memonitor, mengevaluasi diri. Melalui model pembelajaran SVRK, mahasiswa diajak membuat video (merencanakan) kegiatan pertanian dalam berbahasa Inggris, kemudian mahasiswa memonitor proses pembuatan dan praktik bahasa Inggris, lalu memberikan penilaian (evaluasi) hasil video meliputi kosa kata, pronunciation, grammar, dan gerakan-gerakan yang sesuai dengan tema dan topik percakapan.

Model pembelajaran SVRK tidak sekedar mengajak peserta didik (mahasiswa) belajar bahasa Inggris, akan tetapi juga mengajarkan mahasiswa untuk 
AKSARA Jurnal Bahasa dan Sastra

Vol. 19, No. 2, Hal. 68 - 88, Oktober 2018

http://jurnal.fkip.unila.ac.id/index.php/aksara

merencanakan pembelajaran mandiri, memonitor, dan mengevaluasi kegiatan belajarnya. Harapannya, mahasiswa dapat belajar secara mandiri dengan motivasi dan minat yang tinggi.

Bahasa merupakan kemampuan akademik, kemampuan bahasa individu dipengaruhi bagaimana lingkungan disekitarnya memberikan porsi terhadap pemerolehan bahasa itu sendiri (Suhaimi, 2017). Untuk itu perlu pembiasaan pembelajaran bahasa Inggris mahasiswa agar dapat memperoleh porsi yang proporsional. Kemampuan bahasa Inggris mahasiswa perlu ditingkatkan, terutama yang spesifik mengenai latar belakang mahasiswa itu sendiri, seperti mahasiswa pertanian yang harus lebih banyak mengetahui bahasa Inggris tentang pertanian.

Model pembelajaran SVRK yang merupakan pengembangan dari Model pembelajaran Visual Auditori Kinestetik(VAK) untuk diterapkan kepada orang dewasa, dengan harapan pembelajaran bahasa dalam hal ini bahasa Inggris dapat dilaksanakan dengan mudah terutama mengenai bahasa Inggris akademik.

Model pembelajaran VAK menyatakan bahwa pembelajaran akan efektif dengan memperhatikan ketiga gaya belajar tersebut, sebuah penelitian yang dilakukan kepada 5000 lebih siswa di Amerika Serikat, Jepang, dan Hongkong dari kelas 5 sampai kelas 12 menunjukkan kecenderungan belajar Visual 29 \%, Auditori 34 $\%$, Kinestetik $37 \%($ Rose, Colin dan Nicholl,2002). Penelitian tersebut menyatakan bahwa pada saat dewasa, kecendrungan gaya belajar visual semakin meningkat. Demikian pula pada hasil penelitian model pembelajaran SVRK (SelfVideo Recording and Kinesthetic) yang dilakukan oleh peneliti juga cenderung lebih cepat diterima oleh mahasiswa.

Pada penelitian terdahulu, self-regulated learning mampu menunjukkan perkembangan peserta didik dalam meningkatkan kemampuannya belajar. Dari penelitian yang terdahulu yang dilakukan oleh Sucipto (2014) menyatakan bahwa self-regulated learning berpengaruh terhadap hasil belajar SMA Negeri di kota Jombang. Pada pembelajaran atau mata kuliah bahasa Inggris, self-regulated learning sangat membantu guru atau dosen dalam pembelajaran. Dalam penelitian ini, model pembelajaran SVRK dikembangkan untuk meningkatkan self-regulated learning mahasiswa pertanian dalam mata kuliah bahasa Inggris. Hasil penelitian yang lain yang dilakukan oleh Eka Rahil (2013) juga menemukan bahwa peserta didik yang ingin mencapai tingkat prestasi tertinggi, motivasi berprestasi harus dimiliki secara utuh. Artinya, self-regulated learning akan mempengaruhi tingkat partisipasi dan prestasi peserta didik dalam belajar. 
Hasil penelitian ini menunjukkan bahwa $100 \%$ mahasiswa yang menjadi subjek dalam penelitian ini melakukan perencanaan pembuatan video dengan gerakangerakan dan mengevaluasi hasil video tersebut. Peneliti telah menyebar angket untuk responden agar mengisi bagian-bagian mana yang dievaluai diantara empat komponen (boleh memilih lebih dari satu) yaitu dengan hasil merencakan dan mengevaluasi diri (1) kesesuaian gerakan $=92 \%$, (2) pengucapan (pronunciation) $=90 \%,(3)$ tata bahasa (grammar) $=80 \%$, dan (4) kosa kata (vocabulary) $=85 \%$.

Woolfolk (2008) mendefinisikan bahwa self-regulated learning merupakan sebuah proses dimana individu mengaktifkan kognisi, perilaku dan perasaanya. Mahasiswa sebagai individu atau kelompok dengan sendirinya melaksanakan belajar secara mandiri dan langsung untuk memperoleh pengetahuan serta keahlian mereka terhadap keahlian dan kemampuan yang diinginkan tanpa harus bergantung pada dosen dan orang lain secara sistemis dan berorentasi pada tujuan pencapaian belajar.

Dari hasil tersebut dapat diuraikan bahwa model pembelajaran SVRK(Self-Video Recording and Kinesthetic) mampu menumbuhkan perencanaan, penyusunan, pelaksanaan, dan evaluasi belajar mahasiswa dalam belajar bahasa Inggris secara mandiri. Model pembelajaran SVRK (Self-Video Recording and Kinesthetic) dipilih karena model ini menekankan pada praktik pembelajaran bahasa Inggris secara mandiri.

Model pembelajaran SVRK mengajak mahasiswa merencanakan, merancang, dan melaksanakan pembuatan video dengan tema latar belakang mereka, dalam penelitian yang telah dilakukan oleh peneliti yaitu tentang potensi pertanian lokal. Membuat video adalah kebiasaan mahasiswa dan menggunakan tema dan topik latar belakang keilmuan yang sedang ditekuni merupakan motivasi mahasiswa dalam belajar. Model pembelajaran SVRK mengkombinasikan keduanya dalam satu kegiatan untuk mendapatkan hasil yang maksimal dalam pembelajaran bahasa Inggris, mahasiswa akan menjadi terbiasa dan termotivasi untuk berbahasa Inggris.

Setelah kebiasan dan motivasi mahasiswa terbangun dalam berbahasa Inggris, sebagai penguatan hasil maka dosen perlu memberikan arahan mengenai penilaian diri yang disebut self-regulated learning 
AKSARA Jurnal Bahasa dan Sastra

Vol. 19, No. 2, Hal. 68 - 88, Oktober 2018

http://jurnal.fkip.unila.ac.id/index.php/aksara

\section{KESIMPULAN DAN SARAN}

Berdasarkan hasil dan pembahasan tentang pengembangan model pembelajaran SVRK (Self-Video Recording and Kinesthetic) untuk meningkatkan selfregulated learning mahasiswa pertanian dalam mata kuliah bahasa Inggris berbasis potensi pertanian lokal diketahui bahwa pengenalan potensi lokal diperlukan oleh dosen untuk membuat proses belajar yang menarik dan menyenangkan bagi mahasiswa, karena mahasiswa akrab dengan potensi lokal, sehingga mereka hanya fokus pada bahasa yang digunakan dalam membuat alur cerita atau aktifitas yang kemudian direkam dalam video. Selain itu, dosen juga memperkenalkan potensi pertanian lokal Kediri di Indonesia. Dan sebagai penilaian dari ahli, model SVRK adalah direkomendasikan untuk digunakan oleh dosen bahasa Inggris dalam proses belajar mengajar. Hasil penelitian ini juga menunjukkan adanya self-regulated learning mahasiswa dalam pembelajaran bahasa Inggris sehingga mahasiswa mampu mandiri dalam belajar.

Model pembelajaran SVRK (Self-Video Recording and Kinesthetic) tidak terbatas untuk mahasiswa pertanian seperti yang dikembangkan oleh peneliti, namun diharapkan peneliti selanjutnya juga dapat mengembangkan model ini dengan subjek mahasiswa yang lebih luas.

\section{UCAPAN TERIKAKASIH}

Terimakasih peneliti sampaikan kepada DRPM Kemenristekdikti yang telah membiayai penelitian ini pada skema Penelitian Dosen Pemula (PDP), juga kepada LLDIKTI (dh.Kopertis) Wilayah 7 dan LPPM Universitas Kahuripan Kediri yang telah memfasilitasi pelaksanaan penelitian ini, serta pihak-pihak yang telah bersedia menjadi responden.

\section{DAFTAR PUSTAKA}

Adawiyah, R. (2012). Pengembangan Model Konseling Behavior Dengan Tingkat Modeling Untuk Meningkatkan Kemandirian Siswa Wanasari Brebes. Dalam Jurnal Bimbingan konseling, Volume 1, Nomor 1, November 2012, hlm. 21-26.

Baedowi, Ahmad. (2012). Calak Edu (Esai-Esai Pendidikan 2008-2012). Jakarta: Pustaka Alvabet.

Rahil, Eka. (2013). Motivasi Berprestasi dan Self-Regulated Learning (SRL). Dalam Jurnal Ilmiah Psikologi Terapan Volume 1, Nomor 2, Januari 2013, hlm. 66-75

Rasyid, Abdurrahman. (2016). Analisis Potensi Potensi Sektor Pertanian Kabupaten KediriTahun 2010-2014. Dalam Jurnal Ekonomi Pembangunan Volume 14, Nomor 02, Desember 2016, hlm. 100-111

Rose, Colin dan Nicholl, Malcolm J. (2002). Accelerated Learning for the 21st 
AKSARA Jurnal Bahasa dan Sastra

Vol. 19, No. 2, Hal. 68 - 88, Oktober 2018

http://jurnal.fkip.unila.ac.id/index.php/aksara

Century. Jakarta: Nuansa Yayasan Nuansa Cendikia

Samsudi. (2006). Desain Penelitian Pendidikan. Semarang: Unnes Press

Schunk, D. H. (2012). Learning theories: An educational perspective (6th ed.). Upper Saddle River, NJ: Pearson Education, Inc.

Suhaimi, Imam. (2017). Memberdayakan Kecerdasan Kinestetik Anak Untuk Budaya Literasi Bahasa. Dalam Jurnal Kredo, Volume 1, Nomor 1, Oktober 2017, hlm. 7290

VandenBos, G. R. (2007). APA dictionary of psychology. Washington DC: American Psychological Association.

Woolfolk, A. (2008). Educational paycohology active learning edition (terj. Helly P.J., \& Sri M. S 2009). Yogyakarta: Pustaka Pelajar. 